\title{
Извлечение ванадия из техногенных руд сернокислотного производства диоксида титана
}

\author{
А.С. Москаленко, С.Г. Ясев, А.В. Самвелов, К.С. Павлов \\ Акционерное общество «Оптико-механическое конструкторское бюро «АСТРОН», \\ Московская область, г. Лыткарино, 140080, ул. Парковая, 1 \\ тел./факс: +7 (495) 941-6272, эл. почта: $\underline{v @ a s t r o h n . r u ~}$
}

DOI 10.34077/RCSP2019-154

В современном мире получили широкое распространение тепловизионные оптические приборы, приёмником излучения в которых является микроболометрическая матрица. Основной фоточувствительный элемент болометрического приёмника - тонкая пленка на основе оксида ванадия. Получение материалов для изготовления оксида ванадия сопряженно с определенными сложностями, так как ванадий относится к рассеянным элементам, он не имеет собственных месторождений. Именно это даёт предпосылки к тому, чтобы получать ванадий как сопутствующий элемент. Основной задачей современного производства является усовершенствование технологических процессов и схем, внедрение которых позволило бы уменьшить количество отходов и обеспечить их максимальную утилизацию.

При производстве диоксида титана используется сернокислотный метод переработки исходного сырья - ильменита. В ильмените кроме основного вещества - $\mathrm{FeTiO}_{3}$ содержатся такие ценные элементы как: ванадий, цирконий, скандий, тантал, ниобий и другие, которые при выщелачивании ильменита серной кислотой переходят в раствор. После извлечения диоксида титана гидролизом, разбавленная серная кислота поступает в сернокислотные накопители. Учитывая специфику производства диоксида титана, наиболее простым и эффективным методом извлечения ванадия является адсорбция на ионообменниках (комплекситах).

В данной работе нами использовалась технология, основанная на сорбенте ТБФ ТВЭКС ионообменной смолы, полученной из трибутилфосфата, в гранулированном виде. Это твердый экстрагент, продукт суспензионной сополимеризации стирола и дивинилбензола с использованием в качестве активной фазы экстрагента - трибутилфосфата. Данный сорбент помещался в сорбционные колонны, соединенные последовательно, через которые пропускался с заданной скоростью раствор, содержащий соединения ванадия (в основном, сульфат ванадия). После адсорбции в растворе определялась концентрация ванадия, методом спектрофотометрии. Извлечение адсорбированного ванадия проводилось промыванием адсорбционных колонок дистиллированной водой, и в полученном растворе методом спектрофотометрии определялась концентрация адсорбированного ванадия.

С применением технологии на основе сорбента ТБФ ТВЭКС получен раствор сульфата ванадия высокой концентрации, который успешно используется ОА «ОКБ «АСТРОН» для получения оксида ванадия и его соединений, которые в свою очередь используются предприятием для изготовления наноплёнок, необходимых при создании микроболометрических матриц, комплектующих тепловизоры различного назначения.

\section{Лuтература}

[1] В.Н. Музгин и др. Аналитическая химия ванадия. М.: Наука, 1981. 216 с.

[2] А.Ф. Борисенко. Ванадий. М.: Недра, 1973. 115 с.

[3] Ю.А. Золотов Экстракция внутрикомплексных соединений. М.: Наука, 1968. 153 с.

[4] И. Стары. Экстракция хелатов. М.: Мир, 1966. 173 с.

[5] А.К. Бобко. Физико-химический анализ комплексных соединений в растворах. Киев.: Изд. АН УCCP, 1985. c. 85 . 